\title{
ELECTROCARDIOGRAPHIC LEAD SYSTEM AND ITS VECTOR VERIFICATION
}

\author{
J. HANÁK and P. JAGOS̆
}

Department of Diagnostics, Therapy and Prevention of Animal Diseases, University of Veterinary Science, 61242 Brno

Received December 17, 1979

\begin{abstract}
Hanák J., P. Jagoš : Electrocardiographic Lead System and its Vector Verification. Acta vet. Brno, 52, 1983: 67-75.

An electrocardiographic lead system has been developed using semiequidistant and semidirect leads arranged in a tetrahedron fashion. Out of 18 usually registered leads, three were bipolar limb leads, three were unipolar limb leads, three bipolar chest leads, six unipolar chest lead while three bipolar leads were connecting chest and limbs (CR, $\mathrm{CL}, \mathrm{CF}$ ). Within the tetrahedron the leads were in the horizontal, transversal and two side sagittal planes.

The tetrahedron system was verified on 60 thoroughbred horses where it was observed that the atrial vector $P_{1}$ is pointed in a dorsocaudad and left direction from the heart. The vector $P_{2}$ is also directed to the left but more dorsally and caudally than the vector $P_{1}$. The vector $R$ points caudoventrally from the heart to the left. Other vector of the ventricular complex $(Q, S$ and $T)$ are reserved with regard to the main vector $R$. They are directed mainly dorsally and to the left with a small deviation towards cranial (mostly vector Q) or caudal (mostly vector $\mathrm{T}$ ) direction.

The vector examination has shown that the horizontal plane leads represented in the Einthoven arrangement are suitable preferably for following the changes of ECG atrial complex in the horse. On the other hand, the leads from transversal and sagittal planes may be useful for the analysis and interpretation of changes in the ventricular complex (QRS and T).
\end{abstract}

Lead system, ECG, vector, horse.

The introduction of ECG as a modern examination method in clinical praxis represents a further progress both in human and veterinary medicine; it was particularly significant for the development of the science of the function of healthy and diseased heart. The application of ECG in veterinary medicine is oriented predominantly to the general indication useful for the diagnosis of cardiovascular disorders in the racing horse. Moreover, it is valuable also for the diagnosis of changes and adaptation of cardiovascular apparatus in the process of training.

The electrocardiographic and vectorcardiographic interpretation of cardiac changes in the horse is different from that in man. The difference stems not only from the different slope of anatomic and electric cardiac axis (Holmes and Darke 1970) but also from a different course of base line and from the distribution of surface electrocardiac potentials (Chvátal and Hanák 1976). Also the actual activation process of myocardium (Muylle 1975), as well as the course of repolarization (Holmes and Rezakhani 1975) in man differ from those in the horse.

Hamlin and Smith (1965) or Muylle (1975) divide domestic animals and man into two categories using the activation mode (depolarization) of ventricles as a criterion: the 1st category includes man, dog, cat and rabbit while the 2 nd category which is represented by the horse includes also cattle, sheep and pig (ungulata).

The difference in ventricular activation in the horse and other animals of 2nd category consists in a dual character of myocardial depolarization: 1) indirectly - by a uniform activation front of myogenic depolarization from endocardium to epicardium - similarly as in man and animals of 1 st category, 2) directly - by means of a rich network of Purkynje filaments coated with a strong 
layer of connective tissue and functionally isolated from the myocardium cells (Muylle 1975).

Due to the above mentioned differences the lead ECG system for the horse is quite specific. Bearing this in mind, numerous authors subjected to criticism the utilization Einthoven classical system of limb leads in the equine ECG (Brooijmans 1957; Hill 1968; Holmes and Darke 1970 etc.). Other authors have suggested to change the configuration of Einthoven's triangle on limbs and transfer it to chest or they have worked out own lead systems (Macarez 1958; Dubois 1963; Boutte 1964 etc.).

According to Holmes and Darke (1970) the examining ECG technique for horses should be simple but it should work with a sufficient number of leads in order to overcome certain problems connected with an excentric position of heart, nonhomogeneity of the chest environment, irregularities of body surface and other inter-species, interindividual and even intraindividual differences. The classical Einthoven technique as well as other lead systems monitoring the cardiac potentials within only one plane do not fulfill the ideal assumptions of the dipole theory (Sova 1975). That is why various other lead systems such as equidistant and orthogonal are recommended which enable the vector interpretation of ECG in three-dimensional space.

Also in this work we attempted to develop and to verify a suitable ECG lead system which would meet all requirements of modern electrocardiography being at the same time usable for the diagnosis not only in the horse but in all animals of so called 2nd category. The system should respect all electrophysiological rules of the formation, conduction and propagation of the impuls allowing the vector interpretation of ECG in a tetrahedron space.

\section{Materials and Methods}

The classical Einthoven bipolar limb leads (I, II, III) were used as a base for the tetrahedron lead system. They monitor electric cardiac manifestations in the horizontal plane $(\mathrm{H})$ along the transverse (X) and longitudinal $(\mathrm{Y})$ axis, resp. Also in the horizontal plane the unipolar leads (VR, VL and VF) were registered.

Transferring the electrode from the left pelvic limb (F) to the withers region left from processus spinosus vertebrae thoracis $(C)$ the triangular arrangement into the transversal plane $(T)$ was created on the vertical axis $\mathrm{Z}$ and the transversal $\mathrm{X}$ axis. With this plane only two leads were registered. One was placed between the right chest limb and the withers region (CR) while the second was between the left chest limb and withers region (CL).

A similar exchange of electrodes into the left withers region creates the two sagittal planes (S). Their triangles complement the lead tetrahedron system. The sagittal left $\left(S_{L}\right)$ is formed by transferring the electrode from the right chest $\operatorname{limb}(R)$ on withers $(C)$ while the sagittal right plane $\left(S_{R}\right)$ may be created when the left chest electrode $(L)$ is placed on the withers $(C)$. To form the tetrahedron arrangement in this case it is sufficient to monitor only one lead connecting the left pelvic limb and withers region $(\mathrm{CF})$.

Apart from the tetrahedron arrangement also the chest unipolar and bipolar leads were employed. These, together with tetrahedron, represented uniform electrocardiographic lead system.

Unipolar chest leads were arranged on individual places in such a way that they assumed a topographico-anatomically semidirect position towards the corresponding portion of the heart. The leads from right precordium $\left(\mathrm{V}_{1}-\mathrm{V}_{3}\right)$ represent mostly the manifestations of right heart potentials while when used as left precordium leads $\left(V_{4}-V_{6}\right)$ they manifest predominantly the potentials of the left heart. The lead $V_{1}$ was placed in the 4 th -5 th intercostal space on the right in the line intercepting the shoulder joint. $V_{2}$ is placed in the same intercostal space but at the level of elbow joint and the lead $V_{3}$ was positioned at the same level on the sternum. The lead $V_{4}$ was arranged into 5th to 6th intercostal space on the left at the level of elbow joint (the location of the beat of heart apex). The lead $V_{5}$ being localized on the left part of chest is analogical to the lead $V_{1}$ in the right precordium. The last lead from the left precordium $V_{6}$ was located in the withers region to the left from processus spinosus vertebrae thoracis (instead of $\mathrm{C}$ ) where the electrodes forming the tetrahedron were attached.

Bipolar chest leads were arranged to form a triangle $\left(B_{1}-B_{3}\right)$. Lead $B_{1}$ represents a potential difference between the lead locations arranged in a unipolar mode as $V_{2}$ and $V_{4}$ (i.e. between the right and left part of the chest at the level of a elbow joint). The lead $\mathbf{B}_{2}$ expresses a potential difference between the lead locations from the right side, defined in a unipolar fashion as $V_{2}$ and $V_{6}$. The lead $B_{3}$ monitors the potential difference from the left side between the lead locations $V_{4}$ and $V_{6}$.

A STARTEST (Chirana) instrument was used for the registration of ECG potentials, chart speed being $25 \mathrm{~mm} / \mathrm{s}^{-1}$ and calibration $10 \mathrm{~mm}=1 \mathrm{mV}$.

The ECGs taken by the lead system were registered for 60 horses (English thoroughbred) of both sexes aged from 6 months to 4 years. The direction and length of vectors $P_{1}, P_{2}, Q, R, S$ and $T$ was determined in three mutually perpendicular tetrahedron planes (horizontal $-\mathrm{H}$, trans- 
versal - T and sagittal $-\mathrm{S}$ ). The vector evaluation was carried out using the cross-diagram due to Holzmann (see Perlick and Böhme 1967). The results were statistically and graphically evoluated.

\section{Results}

From Fig. 1 it follows that the ventricular complex in the horse is divided into two vectors of the $P$ wave. The vector $P_{1}$ points from right to left in a horizontal plane while caudally it is declined by $17.45^{\circ}$ from the transversal $\mathrm{X}$ axis. The vector $P_{2}$ is, on the other hand, directed more caudally. Its average angle with the $X$ axis is $71.05^{\circ}$ in a caudal direction and it is almost approaching the longitudinal $Y$ axis. In the transversal plane the vector $P_{1}$ assumes also the right-to-left direction, being dorsally declined by $-16.40^{\circ}$ from the transversal axis $X$. The vector $P_{2}$ is even more dorsally declined and with its angle $-46.55^{\circ}$ it is positioned approximately in the middle between the transversal $X$ axis and vertical $Z$ axis. The course of both vectors of the $P$ wave in the sagittal plane is very similar; they are pointed caudodorsally approximately between the longitudinal $Y$ axis and horizontal $Z$ axis $\left(P_{1}=-45.00^{\circ}, P_{2}=-39.15^{\circ}\right)$. The vector $P_{1}$ exhibits, however, greater standard deviation.

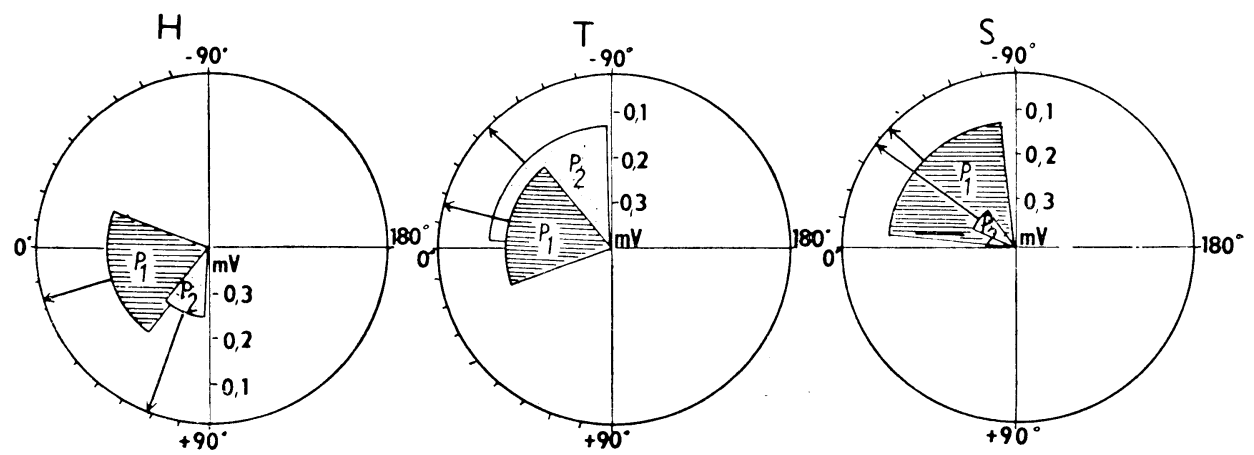

Fig. 1. Direction and magnitude of vectors of atrial complex of the $\mathbf{P}$ wave in three tetrahedron planes $(n=60)$.

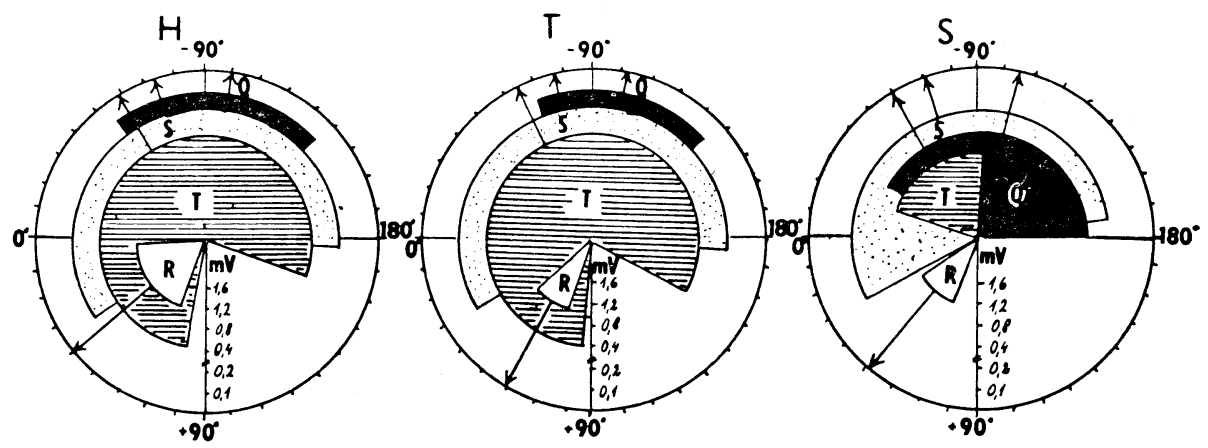

Fig. 2. Direction and magnitude of ventricular complex vectors in three planes of tetrahedron $(\mathrm{n}=60)$. 
The highest absolute value of the vector $P_{1}$ is in the horizontal plane $(0.18 \mathrm{mV})$, while the vectors $P_{2}$ are the greatest in the sagittal and horizontal planes $(0.31 \mathrm{mV}$ and $0.26 \mathrm{mV}$, resp.). Comparing the values of both vectors one can see that $P_{2}$ is greater than $P_{1}$ in the horizontal and particularly in the sagittal plane. The vector $P_{1}$ is, however, greater than $P_{2}$ in the transversal plane.

Fig. 2 shows the direction and magnitude of vectors in the ventricular complex in three perpendicular planes. It follows that the vector $Q$ points in the horizontal plane cranially to the right along the longitudinal $Y$ axis $\left(-100.50^{\circ}\right)$. In the transversal plane it is directed along the vertical axis $Z$ dorsally and to the right $\left(-102.00^{\circ}\right)$. The sagittal plane is characterized by the vector $Q$ which is directed along the $Z$ axis dorsally and cranially $\left(-103.85^{\circ}\right)$. The greatest magnitude of the

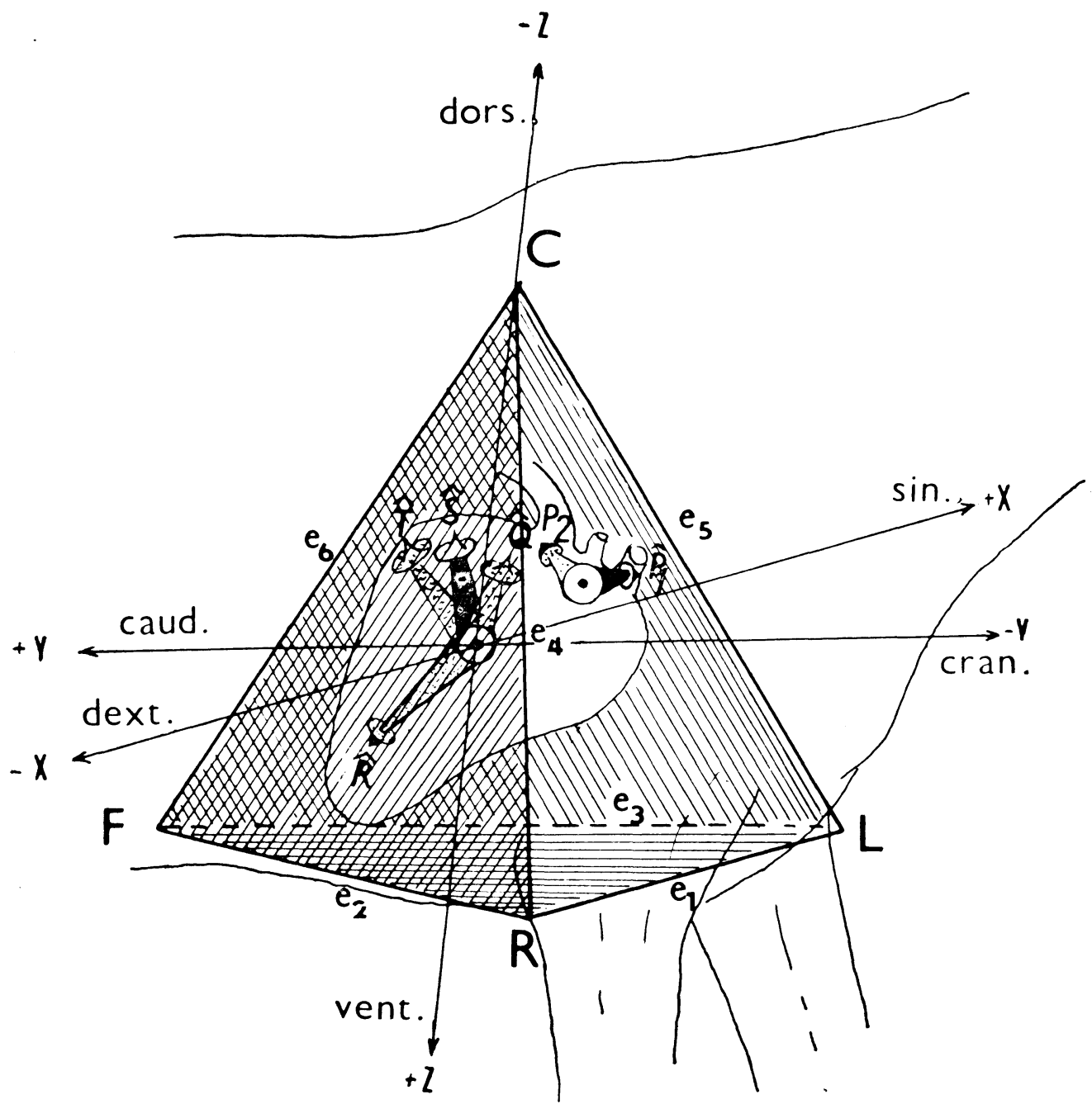

Fig. 3. Direction of vectors of individual oscillations of atrial and venticular ECG complex in the tetrahedron space. 
vector $Q$ is in the sagittal plane $(0.33 \mathrm{mV})$ which is approximately twofold higher value than that in the horizontal plane $(0.16 \mathrm{mV})$ and three times more than in the transversal plane $(0.11 \mathrm{mV})$.

Fig. 2 shows also the angles and magnitudes of the vector $R$. In the horizontal plane the vector $R$ is directed in a caudal direction from right to left pointing approximately in the middle between longitudinal $Y$ axis and transversal $X$ axis. Unlike other planes the angle of vector $R$ is characterized by a high standard deviation $\left(40.40 \pm 35.27^{\circ}\right)$. This is also the reason for the variations of vector $R$ which may range from dextrosinistral to craniocaudal direction. In a transversal plane the vector $R$ is directed from right to left and ventrally between axis $X$ and $Z\left(60.60^{\circ}\right)$. In the sagittal plane it points ventrally and caudally between axis $Y$ and $Z\left(50.90^{\circ}\right)$. The greatest magnitude of the vector $R$ is seen in the sagittal plane $(1.42 \mathrm{mV})$.

The direction of vector $S$, similarly to vector $Q$, is opposite to the direction of vector $R$. It is characterized by a high value of standard deviation in all planes. In a horizontal plane the vector $S$ is directed to the left cranially between axsi $X$ and $Y\left(-72.36^{\circ}\right)$, in a transversal plane to the left and dorsally between axsi $X$ and $Z\left(-77.00^{\circ}\right)$ and in a sagittal plane dorsocaudally between axis $Z$ and $Y$ $\left(-71.00^{\circ}\right)$. Relatively greatest magnitude of the vector $S$ is observed in the sagittal plane but this difference with regard to the other planes is not much pronounced.

The highest standard deviation and thus the highest angle variability exhibits the vector $T$ in the horizontal and transversal plane. In the sagittal plane the direction of vector is relatively constant being directed dorsocaudally between axis $Z$ and $Y\left(-59.45^{\circ}\right)$. The greatest magnitude of this vector is also in this plane $(0.75 \mathrm{mV})$ as compared with the horizontal $(0.60 \mathrm{mV})$ and transversal $(0.41 \mathrm{mV})$ plane.

The results concerning the direction of individual vectors summarized in the tetrahedron space are shown in Fig. 3. It follows that the atrial vector $P_{1}$ is the horse is pointed dorsocaudally and to the left. The vector $P_{2}$ is directed also to the left but more dorsally and caudally than vector $P_{1}$. The vector $R$ is in a caudoventral direction from the heart pointing to the left. The other vectors of the ventricular complex $(Q, S$ and $T)$ have a different course than the main vector $R$. They are directed mostly dorsally and to the right with a smaller deviation in the cranial (mainly vector $Q$ ) or caudal (mainly vector $T$ ) direction.

\section{Discussion}

The developed lead system where the main leads are arranged in a tetrahedron fashion fulfills the requirements of the modern examination electrocardiographic technique as defined by Holmes and Darke (1970). It makes use of the classical conventional leads by Einthoven which are further complemented by a sufficient amount of other special leads in order to overcome the species and individual ECG variations.

The limb leads in the horse monitor the potential differences only in the horizontal plane while in man in the frontal plane. According to the dipole theory (Sova 1975) if the potentials approach this plane they are better manifested on the ECG curve monitored by the limb leads. On the other hand, the potentials directed perpendicularly to this plane are not detected by these leads. In man at the front arrangement of the limb leads into the Einthoven's triangle the direction 
of individual vectors is paralel to this plane (Sova 1975). In the horse, however, the direction of all vectors of the ventricular complex differs from the horizontal plane formed by the Einthoven's triangle, which is documented in Fig. 1. Since the individual vectors of the ventricular complex point more or less perpendicularly to the horizontal plane, the final shape of the QRS complex and the $T$ wave in the limb leads will be different from that in man. In general the amplitude is lower, the mutual ratio of vibrations being also different. This is also characteristic of the ventricular complex in the horse when the Einthoven arrangement is applied for ECG.

As follows from our experiments summed up in Fig. 1, all ventricular vectors are directed to a transversal plane and particularly to the sagittal plane. That is why the potentials of the individual oscillations of the ventricular complex monitored by the leads arranged within these planes (i.e. $C R, C L, V_{6}, B_{2}, B_{3}$ ) are strongly manifested in the ECG curve. The amplitudes of individual oscillations of QRS and $\mathrm{T}$ complexes are considerably greater when compared with the limb leads.

On the other hand, the ECG manifestation of the atrial potentials is quite different. As shown in Fig. 1, both vectors of the $P$ wave are almost parallel to the horizontal plane. For this reason, according to the dipole theory, their amplitude will be most pronounced in the leads arranged in the horizontal plane. This is so not only in the classical limb arrangement due to Einthoven but also in the leads $V_{1}, V_{4}, V_{5}$ and $B_{1}$. Both ventricular vectors are directed to the sagittal or transversal plane in more or less perpendicular fashion, or possibly concurrently. That is why the amplitudes of both peaks of the $P$ wave are quite small in the leads coming from these planes as compared to those from the ventricular complex.

Therefore it follows that the leads from the horizontal plane, including the Einthoven arrangement, are in the clinical ECG of horse suitable particularly for the study and analysis of changes in the atrial complex. On the other had, the leads from other planes, namely the sagittal ones, may be utilized for the analysis and interpretation of changes of the ventricular complex. The Einthoven triangular arrangement on limbs is thus equally necessary for the clinical ECG in the horse as are the other leads with high amplitude of the ECG curve and it yields a number of valuable information. For this reason we made use of the Einthoven's triangle as a base for the developed tetrahedron system and its value for the ECG in the horse was verified.

The tetrahedron semiequidistant arrangement of the leads used in our system when combined with the semidirect or special leads, resp. enables to overcome certain shortcomings connected with the excentric position of heart, irregularities of body surface, non-homogeneity of body milieu etc. Knowing the vector behaviour of individual oscillations in the tetrahedron it is possible, when applying the dipole theory, to interpret both the vector character and shape of any lead in the system, each oscillation and wave of the ECG curve.

So e. g. the first vector of the ventricular complex $Q$ is, according to Muylle (1975) induced by the activation of septum and of the part of the left ventricle wall. This vector is directed in our system craniodorsally and to the right. If this vector is getting farther from the corresponding lead location it induces the first negative vibration $(Q)$. If, on the other hand, the vector is approaching the lead location i. e. it is directed to it, a positive oscillation is seen on the ECG curve (R). Thus the first vector of the ventricular complex induced the $Q$ oscillation in the leads on $Y$ and $Z$ axis or in the sagittal plane. On an $X$ axis in unipolar chest leads from the right precordium $\left(V_{1-3}\right)$ and in $V_{4}$ only a small oscillation $(R)$ appears. 
The leads from the left precordium $\left(V_{5^{-6}}\right)$, however, monitor the oscillation $Q$. The second ventricular vector $R$ is, according to Muylle (1975), due to the activation of the great part of the left ventricle which, having greater volume of myocardium, dominates electrophysiologically over the right ventricle. The second ventricular vector in our system is directed ventrocaudally and to the left. If the second vector is getting farther from the corresponding lead it induced the first positive oscillation (R). If it approaches the lead location it creates the second negative oscillation $(S)$. It thus forms the oscillation $R$ in the leads on axis $Z$ and $X$ (transversal plane) and in the unipolar chest leads $V_{5^{-6}}$. On the $Y$ axis and in other chest leads $\left(V_{1-4}\right)$ this vector, however, produces already a deep oscillation $S$.

The third ventricular vector $S$ is induced by the activation of basal parts of ventricles and of the septum (Muylle 1975). In our system this vector is directed oppositely to the $R$ vector. It thus participates on the terminal part of deflexion $S$ in the leads on the $Z$ axis and in $V_{1^{-4}}$. On the $Y$ and $X$ axis (horizontal plane) and in leads $V_{5-6}$ it participates on the terminal part of deflexion $R$ or on the delay of the intrinsical deflexion.

When interpreting our results taking into account the dipole theory it may be concluded that when the overall resulting vector is approaching the lead location the oscillation $R$ is enhanced. The latter decreases if this vector is turning in the opposite direction with regard to the lead location. The moment during which the vector is touching the lead represents the point of inflexion which is denoted as so called intrinsicoid deflexion (Sova 1975). Using the same approach and the vector scheme in Fig. 1 one can analyse also other parts of ECG, wave $P_{1}, P_{2}$ and $T$. The vector interpretation enables also the elucidation of the ECG curve and its dependence on various factors.

In conclusion it may be said that the suggested tetrahedron lead system was verified and it proved to be useful for the diagnostics in racing horses. The system was studied in order to gain new knowledge in the cardiac electrophysiology in thoroughbreds as representatives of the 2 nd category (divided according to the chamber activation process). This system may thus be applicable not only for the horse but also, after its verification, for other species of domestic animals belonging to this category (cattle, small ruminants, pigs). The tetrahedron lead system enables also the orientation in the vector behaviour of electromotoric cardiac forces in space. On the basis of the vector explanation of changes of the ECG curve from individual leads this system enables a uniform interpretation of ECG in a dependence on various physiological and pathological states of the myocardium.

\section{Elektrokardiografický svodový systém a jeho vektorové ověření}

Byl vypracován elektrokardiografický svodový systém založený na využití semiekvidistantních a semidirektních svodů uspořádaných do jehlanu (tetraedronu). Z 18 obligátně registrovaných svodů jsou 3 svody bipolární končetinové, 3 svody unipolární končetinové, 3 svody bipolární hrudní, 6 svodů unipolárních hrudních a 3 bipolární svody mezi hrudníkem a končetinami (CR, CL, CF). Svody v tetraedronu jsou na rovině horizontální, transverzální a dvou postranních rovinách sagitálních.

Vektorovým ověřením tetraedronového systému u 60 plnokrevných koní bylo zjištěno, že předsínový vektor $P_{1}$ směřuje od srdce dorzokaudálně a vlevo. Vektor $P_{2}$ 
směřuje rovněž vlevo, ale více dorzálně a kaudálně než vektor $P_{1}$. Vektor $R$ směřuje od srdce kaudoventrálně a vlevo. Ostatní vektory komorového komplexu $(Q, S$ a $T)$ mají průběh opačný než hlavní vektor $R$. Směřují převážně dorzálně a vpravo s menší odchylkou směrem kraniálním (nejvíce vektor $Q$ ) nebo kaudálním (nejvíce vektor $T$ ).

Vektorově bylo prokázáno, že svody horizontální roviny, reprezentované Einthovenovým uspořádáním, jsou u koní vhodné především pro sledování změn v předsínovém komplexu EKG. Naproti tomu svody roviny transverzální a sagitální mohou sloužit $\mathrm{k}$ analýze a interpretaci změn v komorovém komplexu ( $Q R S$ a $T$ ).

\section{Электрокардиографическая система отведения и ее векторная проверка}

Была разработана электрокардиографическая система отведения, основанная на использовании полуравноотстоящих и полупрямых отведений расположенных в форме пирамиды (тетраэдрона). Из 18 регулярно регистрированных отведений 3 отведения являются биполярными от конечности, 3 отведения монополярные от конечности, 3 отведения биполярные грудные, 6 отведений монополярных грудных и 3 биполярных отведения между грудной клеткой и конечностями $[\mathrm{CR}, \mathrm{CL}, \mathrm{CF}]$. Отведения в тетраэдроне находятся на уровнях горизонтальном, трансверзальном и на двух посторонних уровнях сагиттальных.

Векторной проверкой тетраэдронной системы 60 полнокровных лощадей было выявлено, что вектор предсердия $\mathrm{P}_{1}$ направлен от сердца дорзальнокаудально и налево. Вектор Р2 идет также налево, однако, в более дорзальном и каудальном направлении, чем вектор Р1. Вектор Р направлен от седрца каудовентрально и налево. Остальные векторы комплекса желудочка сердца ( $\mathrm{Q}, \mathrm{S}$ и $\mathrm{T}$ ) проходят по сравнению с главным вектором $\mathrm{P}$ в противоположном направлении. Они идут преимущественно дорзально и направо с небольшим отклонением в краниальном направлении (больше всего вектор Q) или в каудальном направлении (больше всего вектор $\mathrm{T}$ ).

Векторно было установлено, что отведения горизонтальной плоскости, представляемые расположением Эйнтховена, удобны у лошадей прежде всего для наблюдения за изменениями в комплексе предсердия ӘКГ. В противовес этому, отведения трансверзальной и сагиттальной плоскостей могут служить для анализа и интерпретации изменений в комплексе желудочков сердца (QRS и $\mathrm{T})$.

\section{References}

BOUTTE, J.: Contribution á l'étude de l'électrocardiographie chez le cheval de sport. Choix de nouvelles derivations. Thesis, Lyon, 1960, $60 \mathrm{p}$.

BROOIJMANS, A. W. M.: Electorcardiography in horses and cattle. Theoretical and clinical aspects. Thesis, Utrecht, 1957, 83 p.

DUBOIS, M.: Du chois des dérivations et d'une normalisation de l'électrocardiogramme chez quelques ongulés domestiques. Rec. Méd. Vét., 137, 1961, 425-448.

HAMLIN, R. L. - SMITH, C. R.: Categorisation of common domestic mammals based upon their ventricular activation process. Ann. N. Y. Acad. Sci., 127, 1965, 195-203.

HILL, J. D.: The significance of foreleg position in the interpretation of electrocardiograms and vectorcardiograms from research animals. Am. Heart J., 75, 1968, 518-527. 
HOLMES, J. R. - DARKE, P. G. G.: Studies of the development of a new lead system for equine electrocardiography. Eq. Vet. J., 2, 1970, 12-21.

HOLMES, J. R. - REZAKHANI, A.: Observations on the T wave of the equine electrocardiogram. Eq. Vet. J., 7, 1975, 81-87.

CHVÁTAL, O. - HANÁK, J.: Rozložení povrchových elektrických potenciálů srdce u koně. Vet. Met., 21, 1976, 623-631.

MACAREZ, J. A.: Contribution á l'étude du champ électrique du coeur. Travail experimental chez le cheval. Thesis, Lyon, 1958, 68 p.

MUYLLE, E.: Experimental study of the course of the depolarisation wave in the equine heart. Genesis of the P and QRS complex of the electrocardiogram. Medelingen van de Fac. Diergeneeskunde Rijksuniversiteit Gent, 19, 1975, 191 s.

PERLICK, E. - BÖHME, H.: Elektrokardiographische Untersuchungsmethoden. In Arbeitsmethoden der inneren Medizin. VEB G. Fischer Verlag, Jena, 1967, 100-296.

SOVA, J.: EKG a jiné grafické metody v kardiologické praxi. Avicenum, Praha, 1975, 303 p. 